
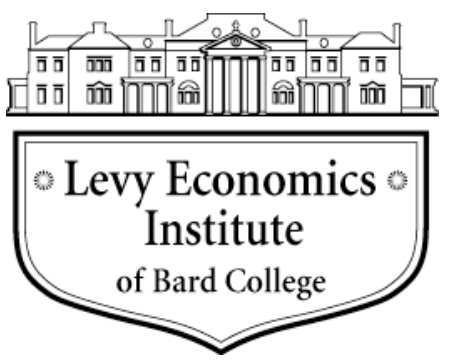

Working Paper No. 649

\title{
Fiscal Policy Effectiveness: Lessons from the Great Recession
} by

\author{
Pavlina R. Tcherneva \\ Levy Economics Institute of Bard College
}

January 2011

The Levy Economics Institute Working Paper Collection presents research in progress by Levy Institute scholars and conference participants. The purpose of the series is to disseminate ideas to and elicit comments from academics and professionals.

Levy Economics Institute of Bard College, founded in 1986, is a nonprofit, nonpartisan, independently funded research organization devoted to public service. Through scholarship and economic research it generates viable, effective public policy responses to important economic problems that profoundly affect the quality of life in the United States and abroad.

Levy Economics Institute

P.O. Box 5000

Annandale-on-Hudson, NY 12504-5000

http://www.levyinstitute.org

Copyright (C) Levy Economics Institute 2011 All rights reserved 


\begin{abstract}
This paper reconsiders fiscal policy effectiveness in light of the recent economic crisis. It examines the fiscal policy approach advocated by the economics profession today and the specific policy actions undertaken by the Bush and Obama administrations. An examination of the labor market renders the contemporary aggregate demandmanagement approach wholly inadequate for achieving certain macroeconomic objectives, such as the stabilization of investment and investor expectations, the generation and maintenance of full employment, and the equitable distribution of incomes. The paper reconsiders the policy effectiveness of alternative fiscal policy approaches, and argues that a policy that directly targets the labor demand gap (as opposed to the output gap) is far more effective in stabilizing employment, incomes, investment, and balance sheets.
\end{abstract}

Keywords: The Great Recession; Fiscal Policy; Macroeconomic Stabilization; Employment

JEL Classifications: E24, E25, E65, J08, J6 


\section{INTRODUCTION}

To many economists the swift and unequivocal support of the profession for fiscal activism during the Great Recession has been somewhat of a surprise. After all, since the late 1970s, most mainstream economists had completely abandoned faith in fiscal policy effectiveness, largely because of the empirically dubious Ricardian Equivalence Hypothesis (see Barro 1974).

Nevertheless, here we are, more than two years after the global financial meltdown of September 2008 , in a position to reconsider the role and place of fiscal policy in stabilizing a devastated economy.

The economist who provided the raison d'être for countercyclical fiscal policy was John Maynard Keynes, whose revolutionary theory (1964 [1936]) transformed the way we understand the functioning of the economy. In reassessing the proper role of fiscal policy today, it should be remembered that Keynes inextricably linked the goal of macroeconomic stabilization to the goal of full employment. He had a very narrow definition of full employment and argued that policymakers had a responsibility to ensure that "everything that could humanly be done has been done by the state ... [to produce] a reduction of the unemployed to the sort of levels we are experiencing in wartime...that is to say, an unemployed level of less than 1 per cent unemployed" (Keynes 1980: 303). This is the definition of full employment that will be used in this paper and I shall argue that achieving and maintaining this level, while simultaneously stabilizing the business cycle, is possible if we carefully heed the Keynesian message.

The principle objective of fiscal policy according to Keynes was to solve "the real problem, fundamental yet essentially simple... [namely] to provide employment for everyone" (Keynes 1980: 267). This objective was nevertheless gradually abandoned by the political process and much of academic economic analysis. Instead, the goal of modern fiscal policy has largely been confined to stabilizing incomes, consumption, and investment, whereas employment stabilization is left to be determined as a byproduct of these policies. Keynes, by contrast, believed that the unemployment problem should be solved speedily and directly by one primary method-direct job creation through public works.

This paper argues that the original Keynesian message can provide both a crucial tool for dealing with the Great Recession and a policy for addressing the unemployment problem at all phases of the business cycle. In particular, it makes the case that conventional aggregate demand 
management policies are inadequate for dealing with the unemployment problem during recessions and incapable of achieving true full employment in expansions. The paper will examine the kinds of fiscal responses that are generally favored by modern economists and policymakers today, as well as the specific policy actions that were undertaken in the United States to deal with Great Recession after the September 2008 financial meltdown. Next, it will overview briefly the labor market conditions in the United States to underscore the inadequacy of the current response. Finally, it will raise and answer the question "what is to be done?" While there are good reasons to believe that the fiscal push was too small, this paper will argue that aggregate demand management cannot establish what Keynes called "a closer approximation of full employment as nearly as is practicable" (Keynes 1964 [1936]: 378-79). Instead, it suggests that what is required is a fundamental reorientation of fiscal policy from one that attempts to close the output gap to one that aims to close the labor demand gap. This approach circumvents a series of shortcomings associated with the aggregate demand management approach. It is a direct approach that delivers macroeconomic stability and addresses the problems of urban blight and rural poverty with its strong regional emphasis. It is a policy that solves the unemployment problem over the long run because it specifically tackles its cyclical, structural, and seasonal components, as well as the problems of the long-term unemployed, the unemployable, the working poor, and the new entrants in the labor market.

\section{MODERN FISCAL POLICY AND THE GREAT RECESSION}

\section{The Conventional View}

Most contemporary economists use the "leaky bucket" analogy to explain how fiscal policy works. Government increases spending for the purposes of boosting GDP growth sufficiently to reduce unemployment to desired levels. Because the fiscal stimulus enters the economy through a leaky bucket (e.g., some of it is lost in transit because of administrative costs and some of it, such as tax cuts and certain investment subsidies, has no direct job-creation effect), not all of the money reaches the poor and unemployed. This leaky-bucket analogy comes from the work of Arthur M. Okun, the economist who inspired the economic "law" that motivates this policy approach. Okun's Law states that a 1 percent increase in unemployment would generate an approximate 3 percent decline in GDP growth. This relationship has been flipped and used as a 
policy guide that lends support to broad-based, pro-growth policies. The law indicates that unemployment can be reduced if the government manages to stimulate growth at a fast enough rate. Note that 3 percent growth in actual GDP (relative to potential output) brings about only a 1 percent reduction in unemployment — a rather small and unimpressive effect (Okun [1962] himself cautioned that the GDP-to-unemployment relationship is rather weak). Although economists generally accept the inverse relationship between growth and unemployment, the exact empirical form of this relationship has received widespread criticism (Altig, Fitzgerald, and Rupert 1997; Lee 2000). From a policy perspective the law does not provide a good guide for government action, even though it motivates the aggregate demand approach. This is because it is unclear what rate or type of growth is required to produce sizeable reductions in unemployment, much less anything close to genuine full employment.

\section{Fiscal Policy during the Great Recession}

Despite the small employment effect stipulated by Okun's law, the general agreement across the theoretical spectrum is that boosting aggregate demand is the proper objective. There is some disagreement on the exact method by which aggregate demand can be expanded, but generally the policy response would include an automatic and a discretionary component. Government spending expands automatically in recessions with the increase in unemployment insurance, welfare benefits, and other transfers to the jobless and the poor. In addition, tax revenues decline with the fall in economic activity, thus boosting the countercyclical government deficit. Furthermore, a number of discretionary moves can be undertaken to hasten the recovery. These normally include additional tax cuts to households and businesses, as well as direct aid to states and firms in the form of grants, contracts, and loans for the purposes of new investment.

The policy response from the G.W. Bush and Obama presidencies in the aftermath of the September 2008 financial crisis followed the general recipe outlined above. It also included a few additional government expenditures, which are not commonly used as countercyclical stabilization measures. The first large injection of government spending took place under G.W. Bush for the purposes of purchasing a large number of nonperforming financial assets from the balance sheets of ailing banks. Although these purchases were executed by the Federal Reserve, they constitute fiscal policy because the Fed cannot purchase private sector liabilities from bank

portfolios without congressional authority. In essence, it is the Treasury with the assistance of the 
Fed that bought a large number of financial assets from private banks. For the purpose, Congress provided the Fed with a budget of $\$ 700$ billion to execute the purchases of asset-backed securities, agency paper, and other assets under the first Troubled Asset Relief Program (TARP). The TARP also facilitated a massive infusion of funds into General Motors and Citigroup and the virtual nationalization of the insurance giant AIG. The objective was to stabilize bank balance sheets to get credit flowing again for the purposes of financing investment.

Whereas fiscal policy was initially used in order to buy nonperforming financial assets from mostly private financial institutions (and to replace them with default-risk-free government assets, namely reserves), it is more frequently used to purchase real goods and services from firms and provide direct income assistance to households and states. Thus the second part of the fiscal stabilization plan was President Obama's American Recovery and Reinvestment Act of February 2009 (ARRA), which appropriated an additional $\$ 787$ billion that included $\$ 288$ billion in tax cuts and benefits to individuals and firms; \$275 billion in contracts, grants, and loans; and $\$ 224$ billion in entitlements. Among the latter, the White House enacted the longest-lasting emergency unemployment program in history that included the first benefit increase in a downturn in history (National Economic Council 2010: 25). Furthermore, it supplemented the Temporary Assistance to Needy Families (TANF) program with emergency funds, which quietly expired by the end of 2010 .

While the budgets for TARP and ARRA alone constituted approximately 10 percent of GDP, they remained inadequate in size and direction, as their net effect on GDP growth or employment was small (Baker 2009). Firstly, as the federal government increased its spending, states, households, and firms continued slashing theirs, offsetting much of the effect. Secondly, these types of injections did not all boost output, as much of the fiscal stimulus (the TARP program in particular) generated demand for non-reproducible financial assets (or what Hahn [1977: 39] called "non-employment inducing demand"). In addition, some of the tax cut payments received by firms and households were used for the purposes of deleveraging. Finally, in the cases when government demand did increase output and production, it did not deliver the employment creation effect that policymakers aimed for. This is largely due to the kind of restructuring that takes place in recessions, which results in a production process that relies on a leaner labor force and low labor costs. 


\section{The Unemployment Situation in the United States}

The misplaced faith in pump priming policies is evident in the dismal employment results the Bush and Obama stabilization packages produced. Upon taking office, president Obama pledged to create or save three to four million jobs. The ARRA specifically intended to prevent significant increases in the unemployment rate and launch a strong jobs recovery. Nevertheless, the White House's projections turned out to be woefully inadequate. The Romer-Bernstein report (2009), which lent support to the ARRA program, estimated that without the stimulus package the unemployment rate would have reached as high as 9 percent, but with a strong fiscal push, it would peak around 8 percent and would quickly turn around. In reality, unemployment peaked at 10 percent after the ARRA was passed and has been hovering around 9.6 percent for over a year and a half with no decline in sight (figure 1).

Figure 1: Unemployment Rate

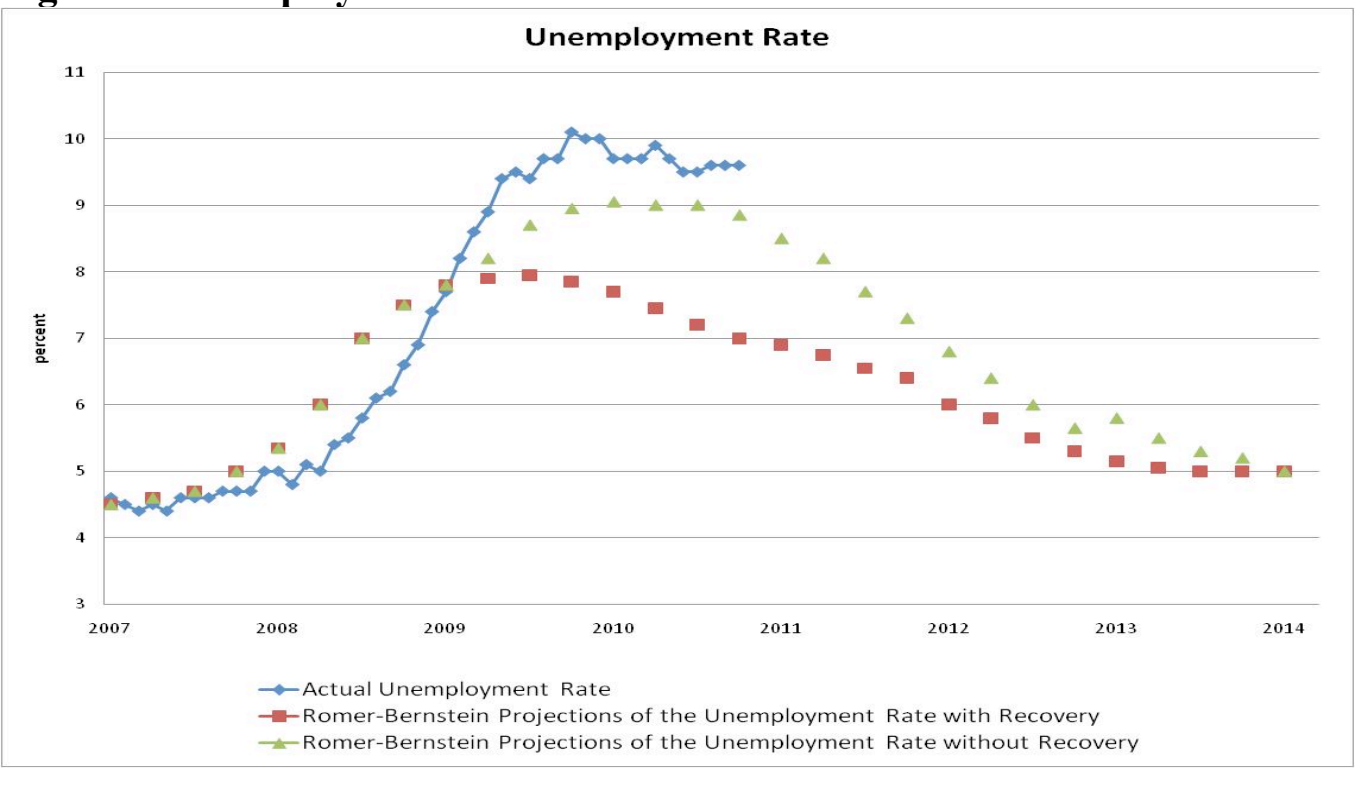

More troublesome is the fact that whatever stabilization we have observed in the unemployment rate is largely due to the mass exodus of discouraged workers from the labor market. The labor force participation rate has been on the longest running decline for the first time in postwar history and the employment population ratio has collapsed to 58 percent-levels not seen in three decades (figure 2). 


\section{Figure 2: Labor Force Participation Rate and Employment-to-Population Ratio}

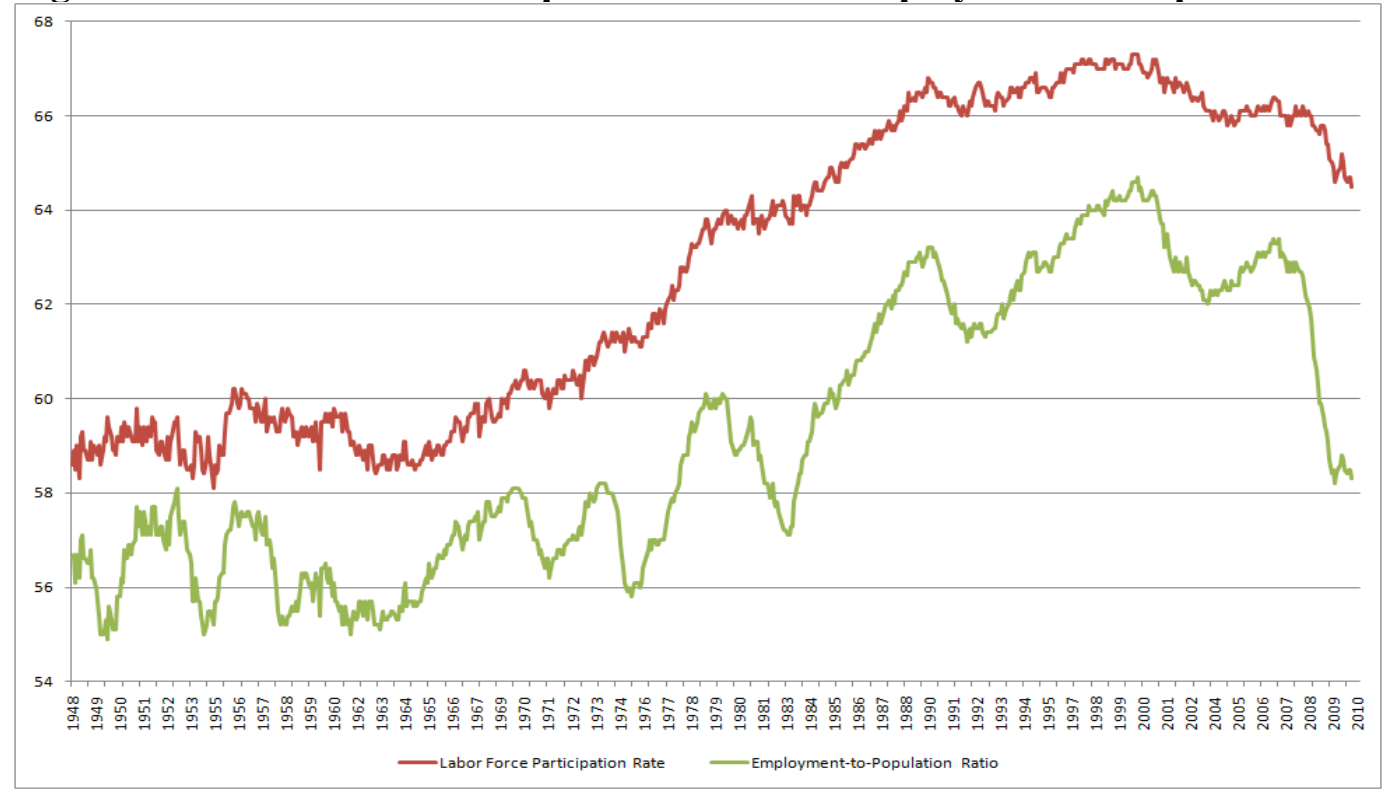

Simultaneously, the labor market is witnessing the wholesale destruction of full-time jobs (figure 3) and record levels of long-term unemployment (figure 4). This latter statistic is particularly disconcerting because the long-term unemployment rate has been on a secular uptrend for the last four decades whereas short-term unemployment has been on a steady decline throughout the entire postwar period. Figure 4 shows the number of people who have been unemployed for 15 weeks or longer as a percentage of total unemployment, as well as those who have been without a job for 27 weeks or more (a subset of the first group). While the series are highly cyclical, their trends have been decidedly up for the last four decades - in every subsequent expansion the long-term unemployment rate has failed to return to its previously low levels. By contrast, the share of the unemployed without a job for 14 weeks or less has been trending down during the entire postwar period (figure 5). 


\section{Figure 3: Full-Time Employment}

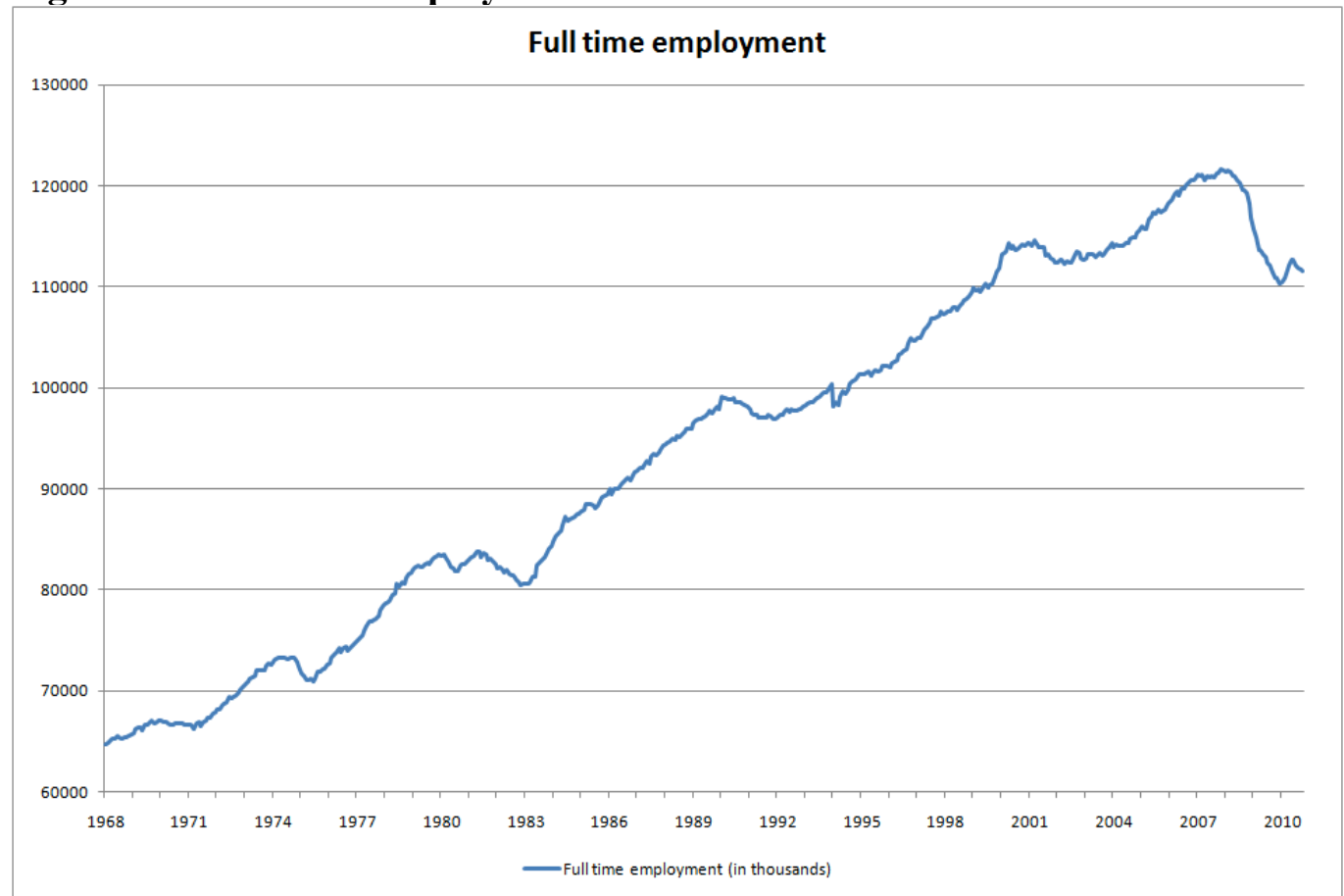

The data shows that an increasing percentage of those who have lost their jobs stay unemployed for longer periods of time, while a falling share of the jobless experience relatively shorter spells of unemployment. This is hardly the agile US economy with dynamic labor markets for the world to envy. Instead, it indicates a sluggish labor market turnover and an inadequate supply of jobs for the long-term unemployed. It is a secular process that indicates the creation of a greater and greater pool of unemployable labor. 
Figure 4: Long-Term Unemployment

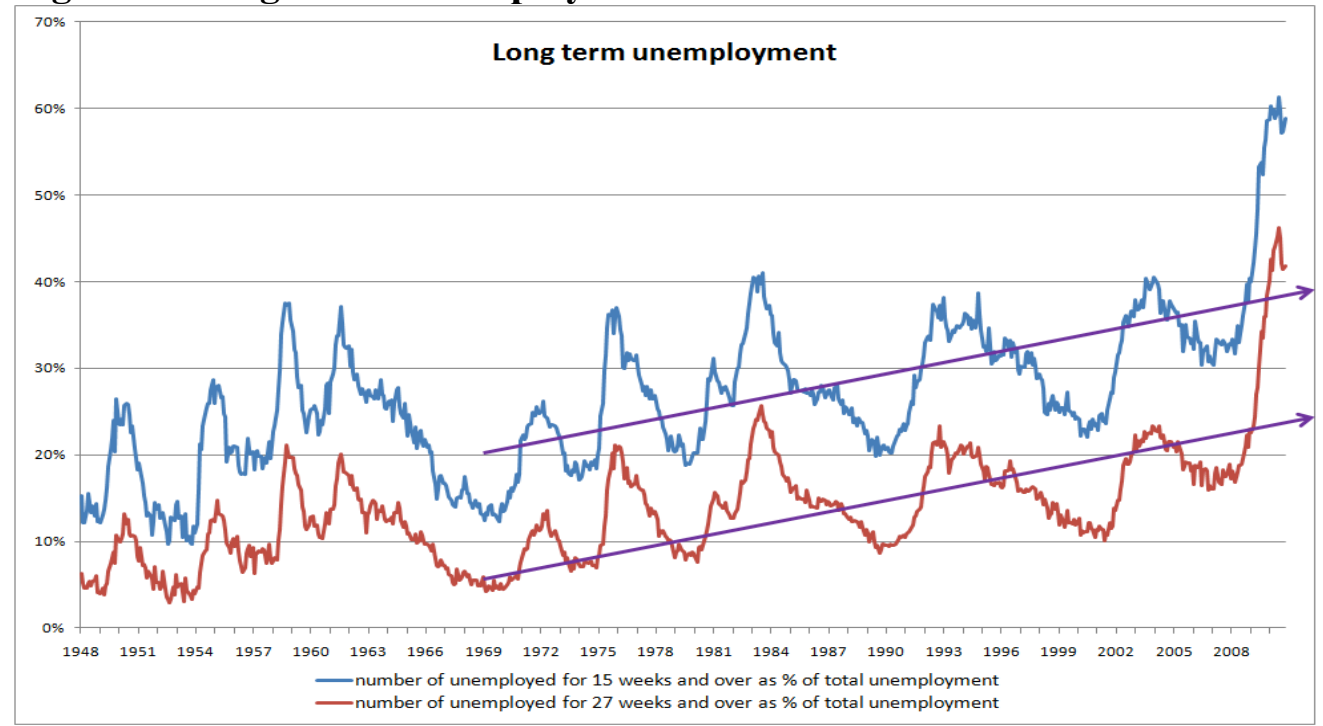

Figure 5: Short-Term Unemployment

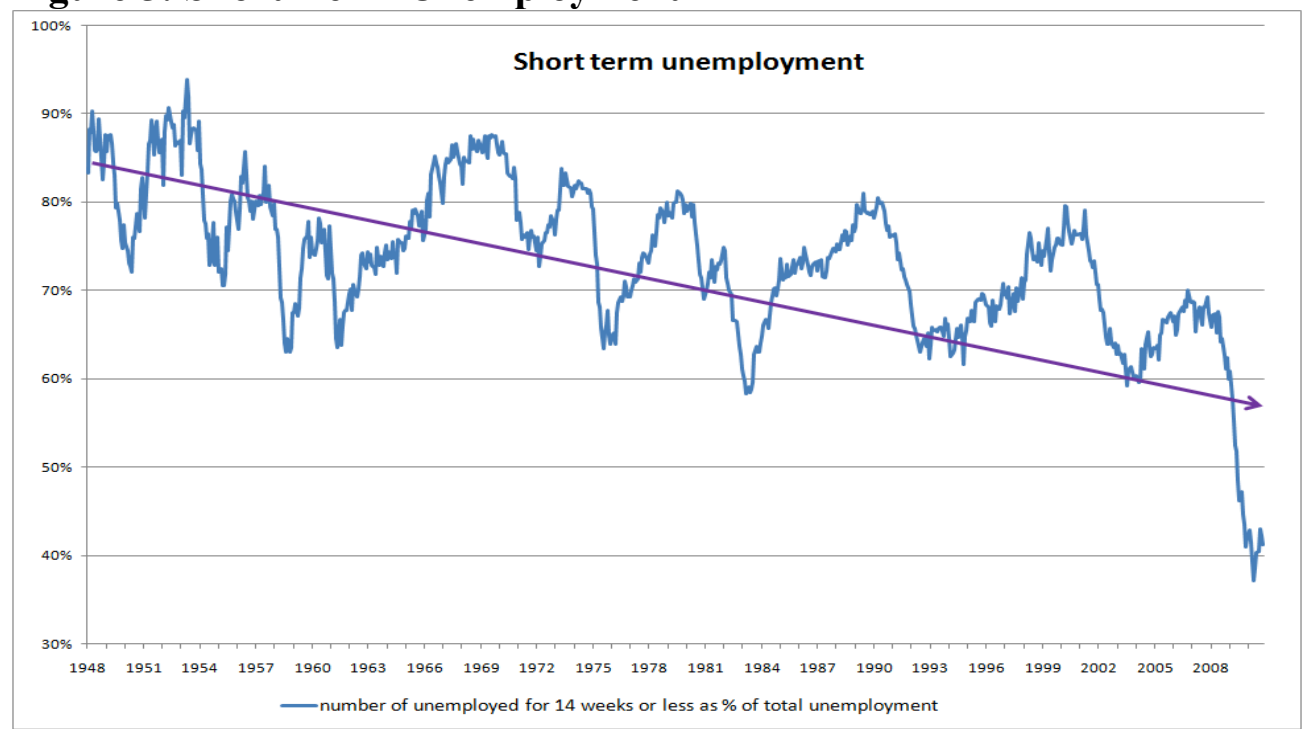

The trouble with the labor market has been brewing well before the Great Recession, suggesting that the temporary aggregate demand management policies that are typically employed in recessions have failed in the past to boldly deal with the unemployment problem and the significant underlying structural problems that have emerged in the US economy. While the fiscal push during the Great Recession has similarly helped put a floor on aggregate demand, it has not generated the vigorous job recovery that is expected or needed. Some economists have correctly argued that the fiscal response was too small (CEPR 2009), but there are good reasons 
to believe that "more of the same" is not the solution to unemployment. If we are serious about achieving and maintaining anything close to full employment, an entirely new approach is necessary.

\section{RETHINKING FISCAL POLICY}

The primary problem with the traditional policy approach is twofold. First, it is implemented in a backward manner. Instead of targeting job creation and allowing growth to be a by-product of a high-employment policy, policymakers target growth, which they hope will generate the desired employment results. Secondly, because fiscal policy is upside down, the pro-growth model has continually failed to achieve anything close to the true full employment level that Keynes advocated, which is why the very objective of full employment has been abandoned altogether and replaced by the "natural unemployment rate" concept (Friedman 1968, Phelps 1994).

Keynes saw nothing natural about any level of unemployment (Keynes 1980: 303) and advocated a targeted approach for dealing with the unemployment problem that focused, not on just any kind of government spending, but specifically on direct job creation via public works. Reexamining the role of public works suggests that genuine full employment can be achieved via a policy of permanent "on-the-spot" employment programs open to all who are ready, willing, and able to work (Tcherneva 2011). The remainder of the paper will make the case that targeting employment directly is the only method for stabilizing an economy that simultaneously generates and sustains full employment over the long run. In sum, the policy approach proposed here is one of labor-demand targeting that would be utilized during all phases of the business cycle.

\section{Misspecification of Fiscal Policy}

As already noted, for Keynes, the principal goal of fiscal policy was to secure true full employment and the principle measure for adjudicating among different policy responses was their employment-creation effects (Kregel 2008). Unfortunately, what is considered to be Keynesian policy today is largely a misinterpretation of the Keynesian prescriptions, which largely stems from a fundamental misidentification of Keynes's theory of effective demand with the theory of aggregate demand (Tcherneva 2011). In the General Theory, Keynes carefully 
articulated that employment determination depended not on the volume of aggregate demand but on the point of effective demand which was very hard to stabilize and fix at full employment.

The conventional textbook theory of aggregate demand deals with the actual components of GDP and argues that, as consumption and investment decline in recessions, the government sector can boost its expenditures countercyclically to offset them. This is because the government is the only sector that can discretionarily change its level of spending. Note that the level of employment does not directly enter into this type of analysis. The main objective is to return the economy to the desirable growth path, as per Okun's Law above. But there is a debate about the specific method by which an economy can be stimulated. Economists who see the downturn as a consequence of the fundamental workings of the economic system that endogenously produce unstable demand prefer a policy response that directly boosts aggregate demand through government expenditure. Economists who see downturns as a direct consequence of some external or exogenous shocks to the system (oil shocks, technology shocks, Katrina-type events, financial shocks, or any other external factors) prefer to work on the supply side and implement policies that deal with market incentives, which in turn are expected to boost consumption and investment independently of government spending, thereby providing a "market solution" to the downturn. Such policy responses would include subsidies to firms, cuts in marginal tax rates, and reduction in wages. In both the demand-side or supply-side cases, however, it is hoped that consumption and investment will recover, either due to the direct government injection of expenditures in the economy or to the various incentives that reduce costs or increase after-tax incomes from employment and production. As a practical matter, modern fiscal policies adopt both demand-side and supply-side responses (such as direct government spending and cuts in marginal tax rates).

By contrast, when Keynes spoke of the problem of unemployment he identified it as a problem of deficient effective demand, not deficient aggregate demand (even if the two are interrelated) (Keynes 1964 [1936]). Put simply, employment in the aggregate is a function of the entrepreneurial decisions of investors, which depend on the expected future earnings that would validate the firms' decisions to hire a given number of people today. In other words, it is the future aggregate demand and aggregate supply conditions that determine employment decisions today. Employment then would depend on both the level and type of future total expenditures and the specific cost structure of production today and in the future. 
More specifically, employment would depend on the percentage of income households decide to hoard (i.e., withdraw from consumption) and the manner in which they save (i.e., whether these savings end up financing real or financial investments). Household saving means that, in the aggregate, not all of the incomes that firms have paid out in wages return back to them in the form of revenues. In this instance, a demand gap develops that must be filled by investment. The liquidity preference of households and firms, however, determines the manner in which they save and the level of investment they undertake. In other words, even when the economy is strong, some of these savings may be locked in non-reproducible and nonemployment generating financial assets. Similarly, in recessions, when profitable investment opportunities are relatively few, the desire to save liquid financial assets is even greater, meaning that aggregate income would fall as households and firms curb consumption and investment and save in increasingly liquid form. In other words, the liquidity preference of the community as a whole, both in recessions and expansions, produces consumption and investment levels that are not consistent with the level of full employment. Keynes also stressed that both consumption and investment are determined by certain subjective and independent factors, such as the marginal propensity to consume ( $m p c$ ), the marginal efficiency of capital ( $m e c$ ), and the marginal efficiency of money (mem), that are not under the direct control of government policy. Thus, to bring the economy to its full employment equilibrium, he argued, government action was required, but not in the form of indiscriminate government spending. This is because boosting aggregate demand alone does not change the independent factors quickly enough in recessions to generate strong job growth. Additionally, and just as importantly, it never improves these factors sufficiently to make them consistent with a level of production where everyone who wants to work has a job.

To put it more simply, even though aggregate demand management fills the coffers of households, firms, and states, their expectations of the future may not improve fast enough to induce them to invest these newly acquired funds into employment-generating activities. In deep recessions in particular, the thirst for liquidity may not be quenched by the supply of more financial assets through government spending. As Keynes had argued, this is because "money is a bottomless sink of purchasing power... [and] there is no value for it at which demand [for it] is diverted ... into a demand for other things" (Keynes 1964 [1936]: 231). In other words when liquidity preference is high, "people want the moon" (Keynes 1964 [1936]: 231) and it is thus 
unclear how large an injection through aggregate demand is needed to induce the private sector to stop hoarding net financial assets and start vigorous consumption and investment. But even when economic activity is buoyant, firms find it unprofitable to hire all who are ready, willing, and able to work. The liquidity preference of some private agents dictates that it is more profitable to invest their savings in money form than in production. Thus, both in recessions and in expansions, unemployment is a monetary phenomenon and, as it will be explained next, both in recessions and in expansions aggregate demand management has specific drawbacks in resolving this problem.

\section{Drawbacks of Aggregate Demand Management}

In recessions, aggregate demand management simply fails to stabilize expectations fast enough and make them consistent with strong employment. In expansions it fails to make them consistent with true full employment. This is because of the peculiar asymmetric nature of aggregate demand. Whereas a sharp decline in aggregate demand will produce a decline in effective demand and employment when it negatively impacts long-term expectations, once expectations become distressed, a sharp boost to aggregate demand will not improve effective demand swiftly. This is because firms, households, and states set certain processes in motion that exacerbate the economic downturn and further worsen expectations. Firms use recessions to slash employment in a process they euphemistically call "right-sizing," in which they streamline the production process and implement labor-saving technologies where possible. Households similarly retrench and rapidly curb their spending. States, whose budgets are highly procyclical, raise taxes and slash social services, investments, and other programs. In addition, if all of these sectors are highly leveraged, as is the case in the current crisis, the readjustments in spending behavior is even more dramatic. For households the pain is particularly severe as many individuals not only lose their sole means of support - their job-but the value of their assets also declines precipitously (e.g., in the form of collapsing retirement portfolios or home values). In the face of such important shifts in behavior, the simple increase in aggregate demand will put a floor on collapsing demand, but will be far less effective in stabilizing expectations fast enough to reverse the job losses that quickly develop.

By contrast, in expansions, boosting aggregate demand does not create full employment even when the economy is strong because it will produce an incrementally smaller employment- 
creation effect the closer the economy gets to full employment. This is because part of the increase in aggregate demand is captured by price increases and not entirely by employment increases. In other words, even when the $m p c$ or mec are very high, the structure of the economy ensures that priming the pump simply produces inflationary pressures in certain overheating sectors where the $m p c$ is high, thus producing more unequal income distribution. This is because, as Keynes cautioned in the General Theory, when "the increase in demand is directed to products with a relatively low elasticity of employment, a larger proportion of it will go to swell the incomes of entrepreneurs and a smaller proportion to swell the incomes of wage earners and other price cost factors" (Keynes 1964 [1936]: 287). This kind of inflationary and income distribution distortions prompt policymakers to abandon aggregate demand policies and leave the economy below full employment or at, what they have subsequently dubbed, the "natural rate" of unemployment.

Thus, while the case for lavish spending to boost GDP is strongest in severe recessions, Keynes was suspicious of the efficacy in this approach. Indeed, although a boost in aggregate demand will improve effective demand, it cannot fix it at full employment. To accomplish this, policy must implement a program of direct spending on employing the unemployed both in recessions and near the peak of the cycle.

Before discussing the advantages of the direct approach over aggregate demand management, a final word is needed about modern supply-side and demand-side policies. It is well-known that Keynes considered attempts to reduce the supply price of output by lowering wages to be counterproductive: because employers will likely be unable to sell the additional output, even if it could be produced at lower cost, they will reduce overall employment in the face of falling demand from falling incomes. Thus, Keynes considered reducing wages to be a "method [that] is socially disastrous in the process and socially unjust in the result" (Keynes 1981: 426).

While aggregate supply policies are clearly counterproductive, aggregate demand management has enjoyed relative popularity because it nevertheless shares some of the important macroeconomic benefits of government spending, even as it fails to produce high employment and better income distribution. 


\section{Macroeconomic Impacts from Government Spending}

There are three key impacts of government spending on the macro-economy. These are: 1) the income and employment effect; 2) the cash-flow effect; and 3) the balance sheet effect (Minsky 1986). These benefits ensue from any type of government spending, however, different fiscal policies will have different employment and distributional effects.

Government spending generates income for the private sector. The volume of public spending will affect the aggregate income in the economy and the direction of the spending will determine the distribution of that income. In the United States it is clear that while GDP has turned a corner, it has not yet posted strong growth. After a zero percent growth rate in 2008 and a 2.6 percent decline in 2009 , the economy is poised to recover at 2.5 percent annual growth rate in 2010 (almost making up for the losses from the previous year). The employment effect from these expenditures, as already noted, has been dismal.

The second, cash-flow effect of government spending, reflects the basic accounting fact that outflows from one sector produce cash inflows to another. When the government awards contracts to firms at a time when firms are downsizing their labor force, government spending directly contributes to private sector profits. ${ }^{1}$ And as the current recession has demonstrated, profits have been recovering in the middle of the recession, whereas employment has not. In

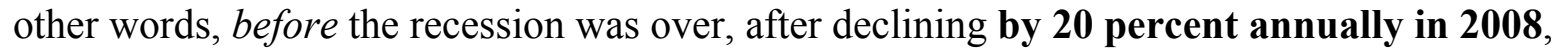
corporate profits after taxes posted a 4 percent gain in 2009. In the 2001 recession, profits also grew, even if little ( 0.5 percent), whereas in the 1990-91 recession profits grew at an average of 8 percent per year (National Income and Product Account statistics). Such quick recovery of profits is quite typical of previous recessions as well-after a short dip they manage to reverse trend quickly. By contrast in every recession, without exception, unemployment has accelerated and then only sluggishly declined over many years during a recovery. In other words, these trends too attest to the fact that policy has become very effective in stabilizing aggregate incomes, profits, and cash flows, but not in stabilizing employment.

The final impact is the balance sheet or portfolio effect of government spending. When states, households, and firms receive cash flows from the federal government, these flows produce stocks of new financial assets in their respective balance sheets. But as cash flows have

\footnotetext{
${ }^{1}$ This is also evident from Kalecki's equation (1954), which shows that government spending is a source of profits irrespective of the business cycle.
} 
been primarily directed to the firm sector (in particular to the financial sector through the TARP program) and to a lesser extent to states (through various grants-in-aid) and households (through unemployment insurance), the balance sheets of firms have experienced greater improvements relative to those of states and households. Nevertheless, the grim profits outlook coupled with still highly leveraged balance sheets of the firm sector make it unlikely that it will boost hiring. Additionally, although households and states are deleveraging, they are still in a weak position to start spending aggressively and lead the recovery. The onus then remains on the federal government sector to continue with its stimulative policies. The challenge is to accomplish this by ensuring full employment. The question then is what type of fiscal policy can do the job.

\section{SETTING FISCAL POLICY STRAIGHT: THE CASE FOR LABOR DEMAND TARGETING}

Because expectations, liquidity preference, and portfolio decisions are subjective and beyond the direct control of policy, Keynes did not believe that policy should attempt to try and stabilize them in order to generate full employment. Instead, for Keynes, the only way to fix the point of effective demand at full employment was for the government to target the unemployed directly. There is considerable evidence to suggest that Keynes had in mind a public policy that would make an unconditional job offer in the public sector to all individuals who are willing and able to work but unable to find private employment (Tcherneva 2011). This job offer would be available to the jobless both in recessions and in expansions. It would be a long-term program for attaining and maintaining true full employment.

Before explaining the reasons why Keynes preferred public works over aggregate demand management, it must be stressed that he considered closing the demand gap - that is the gap between current and potential output — to be a misguided effort. This is because output, measured in real or current prices, gives little indication of the technical considerations and the precise character of the plant in use and of the amount of labor and capital that went into the production of a given level of output (Keynes 1980: 71). Potential output is a particularly troublesome measure (Keynes [1980: 72] called it an "impostor") because estimating it in terms of its market value could not reveal the loss of capital or labor that would occur from any given shift in consumption or investment. Recall that potential output is the only proxy to full 
employment that the traditional fiscal policy approach a la Okun uses. Such a measure of potential output cannot tell us the true full utilization of resources (including labor and capital) over time and may be estimated only for "an instantaneous or brief period of time" (Keynes 1980: 71). For Keynes the only measure of potential output that would make sense would be calculated in terms of man-hours that might be worked (Keynes 1980: 73). Targeting the labor gap however - that is the gap between the number of people who are working and those who are willing to work in the aggregate - is a proper policy objective that can only be achieved through direct job creation.

There are three main benefits of the direct job-creation approach over alternative fiscal policies. First, it delivers the highest employment-creation impact due to its sizeable primary and secondary employment effects. Second, it circumvents the problem of fixing the point of effective demand at full employment by managing the independent factors of consumption and investment (the $m p c, m e c$, and $m e m$ ) and hires the unemployed directly. Thus, a permanent direct job-creation program open to all would maintain full employment throughout all phases of the business cycle. Finally, this approach has a direct method for dealing with structural unemployment, which is generally neglected by traditional aggregate demand management policies (indeed, many economists consider structural unemployment to be part of the "natural unemployment" rate). By contrast, the direct job-creation approach would target its employment efforts to regions that may have experienced massive job losses due to restructuring and to individuals who may be deemed unemployable by those private industries that are employing. The direct job-creation program would provide not only on-the-job experience but would also be supplemented by training and education programs that would upgrade the skills of those individuals to help them transition to private sector work. Additionally, the program would be a safety net that provides an opportunity when there is none to new entrants into the labor force and individuals who have difficulty reintegrating into private sector work, such as stay-at-home moms with long gaps in their work experience, at-risk youth who have difficulty completing high school, elderly who wish to work but are being displaced by a younger and/or cheaper labor force, or welfare recipients who need to find work in exchange for the welfare support they receive but who are unable to find private sector employment. 


\section{Notable Characteristics of the Direct Job-Creation Approach}

There are several aspects of this approach that must be emphasized. First, direct job creation through public works or public service is not a "depression solution." Instead it is a solution to unemployment at all stages of the economic cycle. As already explained, even a strong economy fails to provide jobs for all. Such a program would be a safety net for the jobless in expansions as well.

Secondly, the goal of this program is to provide decent jobs to its participants. These are jobs that use the available idle resources to meet some unfilled need in the community and which establish a basic but decent wage-benefit package as a standard for the economy as a whole. These jobs do not compete with private sector pay, but simply set a universal floor to wages in the public and private sectors. They do not compete with private sector output either, as they are jobs that provide public goods and services, which the private sector does not supply.

Thirdly, job support to the poor and unemployed is a more effective stabilization method than providing income alone. This is because this policy would maintain and enhance human capital and would simultaneously increase both aggregate demand and aggregate supply. By contrast, income support for the unemployed and the poor is a policy that leaves many willing and able to work individuals in idleness and (often) for long periods of time - it is a policy that wastes human potential.

Fourth, this is a policy that does not rely on boosting aggregate demand to produce full employment. Even in severe recessions, when a great fiscal push is needed, this push must nevertheless be targeted. Today, for example, we need both more and better distributed demand - that is, more spending that is targeted to hiring the unemployed. Once a program of this kind is in place, not more demand, but better distributed demand, will be required to maintain full employment over the long run. Keynes himself argued during the buoyant interwar period that "we are in more need today of a rightly distributed demand than of a greater aggregate demand" (Skidelsky 2001: 21). As the economy expands and public sector workers find employment in the private sector, such a program will shrink and full employment will be consistent with lower public sector demand.

Fifth, the first aim of this program is to provide jobs for all, but once the unemployed have been hired, "there can be only one object in the economy, namely to substitute some other, better, and wiser piece of expenditure" for individual projects (Keynes 1982: 146), i.e., to 
redesign those public works to address the specific challenges of specific communities as the need arises. Thus, contrary to common myth, Keynes did not advocate the creation of useless project for the sake of job creation but strongly advocated a carefully planned long-term full employment program - a program that was flexible, spontaneous, and experimental enough to accommodate any new unemployment that might quickly develop, but that was also carefully thought out and designed to address the key strategic objectives of a nation, while maintaining full employment over the long run.

Sixth, such a program could be executed through public or semipublic bodies. Job creation is done by the community as a whole, including both the private and public sectors. But as Keynes pointed out, it really wasn't the business of the private sector to guarantee full employment "any more than it is their business to provide for the unemployed by private charity" (Keynes 1982: 151). It was the responsibility of the public sector to figure out how to employ those who were left behind. And employing them could be done in cooperation with the private sector in public-private partnerships that would manage this long-term program.

Seventh, this very policy would have the exact same income, cash-flow, and balance sheet effects that traditional aggregate demand management has, except that spending by the program would be targeted directly to households. It is a genuine bottom-up approach to economic recovery. It is a program that stabilizes the incomes and purchasing power of individuals at the bottom of the income distribution that trickles up and stabilizes the rest of economic activity. Strong and stable demand means strong and stable profit expectations. A program that stabilizes employment and purchasing power is a program that stabilizes cash flows and earnings. Stable incomes through employment also mean stable repayments of debts and greater overall balance sheet stability.

Finally, Keynes firmly objected to using unemployment as an inflation-fighting measure. If inflationary pressures developed near full employment, the public sector should retard new projects where possible and redirect its job creation efforts to particularly distressed areas in the periphery of economic activity. But by no means should it discontinue public works, because that is precisely the time when "private enterprise is stopping from overcapacity and is therefore not in a position to expand" (Keynes 1982: 150). Inflation, for Keynes, was to be addressed through various programs that would either defer payments or encourage thrift, but would not slash jobs. 
These are the key features of a permanent program for full employment that is consistent with the Keynesian message and policy proposals. But to design such a program, a bold and imaginative approach is required, which weds fiscal policy to the goal of full employment. Not only has aggregate demand management failed to do so over the last several decades but the current ARRA program is particularly weak on imagination, considering the formidable labor market challenges today.

\section{Final Considerations of Some Conventional Objections}

This program is not a panacea for all labor market problems. It is a solution to the problem of unemployment over the business cycle that stabilizes the floor to aggregate demand more effectively than conventional pump priming policies. Neither is this a program a substitute for all other meaningful fiscal policies. It is a voluntary safety net for all of the unemployed who wish to work. There will, nevertheless, remain certain segments of the population who will require income assistance such the young, the ill, or the elderly and they need to be supported through programs like universal child credits, Medicare, or social security. At the same time, governments will continue to be responsible for setting tax policies in a way to affect the income distribution and promote or discourage certain types of private sector activities that advance or harm the public interest.

Governments can use these tax policies to set investment or consumption on a more sustainable path if they are deemed to be wasteful, speculative, or destabilizing to overall economic activity. Nothing precludes governments from instituting important structural changes that would spur private domestic employment. This may include providing support to specific industries that the government may want to encourage- - e.g., tax benefits and investment subsidies for green energy production. These are macroeconomic structural policies that may be warranted on their own merits, but these are not policies for full employment. The private sector has its own considerations that may conflict with the objective of hiring all individuals who wish to work. Therefore, wedding industrial policy that aims to spur private sector activity with the objective of generating private sector full employment may neither be possible nor desirable. Instead, there must be a public program that would stand ready to absorb all of the remaining unemployed individuals who have not found employment in these new industry ventures. In other words, there has to be a policy that takes workers as they are and that tailors the jobs to 
these workers in order to help them enhance their skills, gain the necessary work experience, and start climbing the economic ladder. By contrast, the private sector is in the business of looking for specific people with specific skills to fit specific jobs requirements. It is not in the business of providing jobs for all. But if the private sector faces a shortage of skilled workers, the public sector can work to prepare and upgrade the skills of the formerly unemployed public sector workers for the needs of modern private sector production. This visible public sector pool of labor will give firms a very clear idea of the work experience, training, and education these workers have acquired and their suitability for private sector employment.

Such a policy is not just an alternative to idleness, it is a policy that puts money in households' coffers through employment. It is also a policy that fills the communities' needs gap. This brings us to the final common criticism of public works: namely, that they are administratively difficult to run, prone to corruption, and cannot provide enough useful projects for the unemployed to do. The answer to the first charge is that administrative complexity is pervasive both in the private and public sectors and has hardly stopped firms or governments from undertaking important large-scale initiatives - be they providing global financial services, running military operations, or supporting medical scientific research. Neither are problems with fraud and corruption somehow unique to public sector operations. Pervasive fraud in the private sector, as in the Savings and Loans crisis of the 1980s, the Enron scandal of the 1990s, or the mortgage origination and securitization of the 2000s, should put those old arguments to rest. Fraud and corruption are a function of poor regulation and enforcement and every going concern, private or public, must have design features that enhance transparency and accountability.

The question of useful projects is perhaps the most frequently evoked. One way to answer this question is to note that even in the wealthiest and most prosperous nations one can always find rural or urban regions that are continually plagued by poverty and unemployment. In the case of the United States, there are whole cities and states which have suffered from deindustrialization or natural disasters and have seen little new economic activity to replace long-gone industry (think of Detroit or New Orleans). The revitalization of inner cities and rural areas alone will take years of strong job creation and dedicated work in order to rebuild those communities. The unemployed themselves will deliver that revitalization through a public employment program similar to the New Deal of the 1930s. But wealthier communities too have unfilled needs and unemployed individuals who can fulfill them. These may include upgrades to 
infrastructure, the construction of more public spaces, and the provision of public services. In the United States, many public programs and government services have been underfunded and understaffed for decades — at least since Nixon's devolution of federal government programs. A once-strong public education system is on the brink of collapse, environmental standards have been eroded, the public health system is unfit to meet the needs of the US population - these are the challenges that can be met by fully utilizing labor resources. There are jobs to be done at every level of government and there are unemployed individuals with different levels of skills and education to do them. The examples provided here primarily include the regular maintenance and operation of public service jobs for which the government is already responsible. Other such examples would include an ongoing program of reforestation, water purification, and soil erosion improvements, which will provide steady but flexible public sector employment for many semiskilled and unskilled workers over the long run. The wholesale upgrade of US roads, rails, levies, and bridges can also be accomplished with a bold program of direct job creation. At the same time, child- and elderly-care services are wholly inadequate in this country. Homeless shelters are bursting at the seams and a staggering 12 percent of Americans rely on food banks for food assistance (Hunger Report 2010). There are many jobs to be done and there are many unemployed people to do them.

But the government can also undertake novel strategic initiatives that can be accomplished expediently only through a big-push policy of public works. The comprehensive weatherization of all public buildings and the complete transformation of current energy production grids to ones relying on alternative energy require the kind of massive infrastructure investment that only government can undertake. There are many more useful jobs one could create if the will to implement such a program was there. Clearly no country is a finished proposition. As countries grow, they face new challenges and develop new kinds of needs. The public sector can stand ready through a program of direct job creation to provide jobs for all who wish to work in projects that satisfy those needs. 


\section{CONCLUSION}

The Great Recession provided us with an important "teachable moment" to uncover the drawbacks of the standard policy response and to set fiscal policy straight. It also provided policymakers with an important moment for action, which may have unfortunately already passed. Two years after the financial crisis, the public has gone weary of massive government expenditures that have delivered so little in terms of job creation and will likely not support another large round of stimulus spending. What we seem to face ahead is stagnant growth, high unemployment and income inequality, increasing impoverishment, and a continual squeeze of the middle class. The aggregate demand stimulus may allow the US economy to muddle through the next ten years, but it would be at the cost of great human suffering and worsening labor market conditions. Worse yet, if the current calls for fiscal austerity translate into actual laws, the future may be very grim indeed. We would be wise to remember Hoover's and Roosevelt's early attempts to balance the budgets in the midst of an economic downturn, which only plunged the economy further into the Depression. It is thus critically important that economists and policymakers reconsider the model of macroeconomic stabilization and go to the heart of this crucial problem of unemployment by tackling it directly. 


\section{REFERENCES}

Altig, D., T.J. Fitzgerald, and P. Rupert. 1997. “Okun's law revisited: should we worry about low unemployment?" Economic Commentary, May 15. Cleveland: Federal Reserve Bank of Cleveland.

Baker, D. 2009, Testimony before the House Financial Institutions Subcommittee of the Financial Services Committee, March 4. Available at: http://www.house.gov/apps/list/hearing/financialsvcs_dem/baker030409.pdf.

Barro, R.J. 1974. “Are government bonds net wealth?” Journal of Political Economy 82(6): 1095-1117.

Center for Economic and Policy Research (CEPR). 2009. "Economists who make the third stimulus honor roll." Available at: http://www.cepr.net/index.php/pressreleases/interactive-press-releases/economists-who-make-the-third-stimulus-honor-roll/

Friedman, M. 1968. “The Role of Monetary Policy." American Economic Review 58(1): 1-17.

Hahn, F.H. 1997. "Keynesian Economics and General Equilibrium Theory: Reflections on Current Debates." in G. C. Harcourt (ed.), The Microeconomic Foundations of Macroeconomics. London.: Macmillan.

Hunger Report. 2010. Hunger in America, National Report prepared for Feeding America, January. Available at: http://feedingamerica.issuelab.org/research/listing/hunger_in_america_2010 national_rep ort

Kalecki, M. 1954. Theory of Economic Dynamics: An essay on cyclical and long- run changes in capitalist economy. London: George Allen and Unwin.

Keynes, J.M. 1964[1936]. The General Theory of Employment, Interest, and Money, New York: Harcourt-Brace \& World, Inc.

. 1980. "Activities 1940-46. Shaping the Post-War World: Employment and Commodities.” in Donald Moggridge (ed.), Collected Works, volume XXVII. London: Macmillan.

- 1981. "Activities 1922-29. The Return to Gold and Industrial Policy: Part II." in Donald Moggridge (ed.), Collected Works, volume XIX. London, U.K.: Macmillan.

1982. "Activities 1931-39. World Crises and Policies in Britain and America." in Donald Moggridge (ed.), Collected Works, volume XXI. London: Macmillan.

Kregel, J.A. 2008. "The Continuing Policy Relevance of Keynes's General Theory," in M. Forstater and L.R. Wray (eds.), Keynes for the $21^{\text {st }}$ Century: The Continuing Relevance of The General Theory. London, U.K.: Macmillan. 
Lee, J. 2000. "The Robustness of Okun's Law: Evidence from OECD Countries," Journal of Macroeconomics 22(2): 331-56.

Minsky, H.P. 1986. Stabilizing an Unstable Economy, New Haven, CT: Yale University Press.

National Economic Council. 2010, "Jobs and Economic Security for America's Women." October. Available at: http://www.whitehouse.gov/sites/default/files/Jobs-andEcomomic-Security-for-Americas-Women.pdf

Okun, A. 1962. "Potential Output: Its Measurement and Significance." in Proceedings of the Business and Economic Statistics Section, American Statistical Society. Washington, DC: American Statistical Association.

Phelps, E. 1994. "The Origins and Further Development of the Natural Rate of Unemployment," in R. Cross (ed.), The Natural Rate Twenty-Five Years On. Cambridge, UK: Cambridge University Press.

Romer, C. and J. Bernstein. 2009, "The Job Impact of the American Recovery and Reinvestment Plan." January 10. Available at: http://otrans.3cdn.net/45593e8ecbd339d074_13m6bt1te.pdf

Skidelsky, R. 2001. John Maynard Keynes, Volume Three: Fighting for Britain 1937-1946. London: Macmillan.

Tcherneva, P. 2011. "Permanent on-the-spot job creation — the missing Keynes Plan for full employment and economic transformation." Review of Social Economics, forthcoming. 